\title{
CHANGES IN THE PHYSICAL PROPERTIES OF PRECIPITATION IN PINE STANDS IN THE AREA WITH A LOW DEGREE OF AIR POLLUTION (WESTERN POMERANIA)
}

\author{
ROBERT KRUSZYK \\ Institute of Geoecology and Geoinformation, Adam Mickiewicz University in Poznań, Poland
}

Manuscript received: May 10, 2013

Revised version: July 5, 2013

\begin{abstract}
KRUSZYK R., 2013. Changes in the physical properties of precipitation in pine stands in the area with a low degree of air pollution (Western Pomerania). Quaestiones Geographicae 32(3), Bogucki Wydawnictwo Naukowe, Poznań, pp. 27-37. 2 tables, 4 figs. DOI 10.2478/quageo-2013-0017, ISSN 0137-477X.
\end{abstract}

ABSTRACT. The study presents the results of research conducted in the years 2010-2012 in pine stands in Western Pomerania. The research included physicochemical properties of bulk precipitation and throughfall. The results confirm that despite a decrease in the total throughfall in the interception process, the size of mineral and organic depositions in pine stands exceeded values recorded for bulk precipitation. It was caused both by the process of enriching the throughfall with $\left(\mathrm{K}^{+}, \mathrm{Mg}^{2+}\right)$ rinsed out of needles and leaves and by washing off the dry deposition $\left(\mathrm{NH}_{4}^{+}, \mathrm{Cl}^{-}, \mathrm{Na}^{+}\right.$, $\mathrm{SO}_{4}^{2-}, \mathrm{NO}_{3}^{-}$). The share of leaching processes for $\mathrm{K}^{+}$was $74.1 \%$, while for $\mathrm{Mg}^{2+} 23.6 \%$ of the total load of these elements brought to the ground with throughfall. In the case of $\mathrm{Ca}^{2+}$ no canopy leaching was observed for this element. The throughfall acidification processes were mostly caused by $\mathrm{NO}_{3}^{-}$.

KEY WORDS: Forest ecosystem, throughfall, ion deposition, canopy leaching, Scots Pine

Address of the corresponding author: Robert Kruszyk, Adam Mickiewicz University, Institute of Geoecology and Geoinformation, Dzięgielowa 27, 61-680 Poznan, Poland; e-mail: rlk@amu.edu.pl

\section{Introduction}

In forest ecosystems, precipitation after dampening the plant surface (interception) permeates directly to the bottom of the forest as throughfall (water and snow falling or dripping down from tree crowns and stemflow (water running down branches and trunks) (Parker 1983). Both throughfall and stemflow change their chemical properties upon contact with the plant surface. This is influenced by both processes of washing off dust and gas pollution set on the plant surface and leaching elements from needles and leaves or selected ions uptake from precipitation (Van der
Mass et al. 1991, Likens et al. 1995, Grodzińska et al. 1996, Dambrine et al. 1997, Draaijers et al. 1997, Walna et al. 1999, Polkowska et al. 2005, Małek et al. 2008, Kozłowski et al. 2012). These changes do not only include an increase in throughfall and stemfall mineralisation, but they also influence the acid-base balance of precipitation in forests. As a result of acidic compounds (sulphur and nitrogen) set on the plant surface being washed off, the $\mathrm{pH}$ of precipitation in forests is lowered, which ultimately causes soil acidification (van Breemen et al. 1982, Gower et al. 1995, Walna et al. 1999, Kvaalen et al. 2002, Bochenek et al. 2008). On the other hand, by hydrogen ion uptake pro- 
cesses and their replacement in precipitation with base cations $\left(\mathrm{K}^{+}, \mathrm{Ca}^{2+}, \mathrm{Mg}^{2+}\right)$ from the canopy, the plants neutralise the acidification present during precipitation, thus contributing to the lowering of their acidity (Van Breemen et al. 1982). Conifer stands modify the chemical properties of precipitation to a much higher degree (Gower et al. 1995, Butler, Likens 1995, Shubzda et al. 1995, Kozłowski et al. 2012). The presence of needles during the whole year and a higher-reception surface area, as compared to leaves, contribute to an increase in the pollution inflow to the soil, despite the reduction of water inflow during the interception process. The intensity of the processes of precipitation enrichment in mineral and organic ingredients in forests depends on: the tree stand type age and structure and the content and type of pollution present in the air. It is assumed that the intensification of base cations leaching from the canopy occurs when the acidic atmospheric deposition is present (Draaijers et al. 1997, Polkowska et al. 2005, Małek et al. 2008).

The aim of the study included the determination of: (i) the scale of changes in the chemical properties of precipitation in pine stands, (ii) the load of base cations $\left(\mathrm{K}^{+}, \mathrm{Ca}^{2+}, \mathrm{Mg}^{2+}\right)$ leached out of the canopy and (iii) the degree of throughfall acidification as compared to bulk precipitation.

\section{Research area, tree stand description}

The research stand was located in the area of the catchment area of the upper Parsęta River in West Pomerania $8 \mathrm{~km}$ north-west of Szczecinek. The catchment area of the upper Parsęta River is situated on the borderline between two mesoregions: The Drawskie Lakeland and the Bytów Lakeland. In the use structure of the catchment area, coniferous forests occupy $21.1 \%$ of the catchment area $\left(74.0 \mathrm{~km}^{2}\right)$ (Zwoliński et al. 2010). Beech and oak stands, which originally occurred in this area, were supplanted by Scots pine monocultures.

Research was conducted in a pine stand situated in the area of the Szczecinek Forest Division - Szczecinek forest circle, division 36d. On the basis of phytosociological tests, the tree stand under analysis was defined as suboceanic fresh coniferous forest, Leucobryo-Pinetum. The age of the pine stand was estimated at 92 years. The pine is the dominant species in the tree layer with the estimated density of $70 \%$. The average diameter at breast height of trees from this species was 33.8 $\mathrm{cm}$, while the average height was $24.7 \mathrm{~m}$.

The soil cover of the test area was classified as a subtype of rusty podzolic soil formed from mid-grained sand deposits. The $\mathrm{pH}$ values obtained allowed for classifying it as buffered soil in the area of the exchange and clay buffer with small buffering properties in the acidic buffer (Kruszyk 2002).

\section{Research methods}

The results presented include the period of three hydrological years: 2010, 2011 and 2012 (from 13 November 2009 to 6 November 2012). The measurement system included 12 throughfall collectors situated under tree crowns at regular mesh nodes at 4-metre distances (Fig. 1). The method of location, type and number of collectors were consistent with the principles of throughfall monitoring within the Integrated Monitoring of the Natural Environment programme (Kostrzewski et al. 2006). Collector inlets were placed 20 $\mathrm{cm}$ above the ground level and they were protected by a mesh from the organic material getting

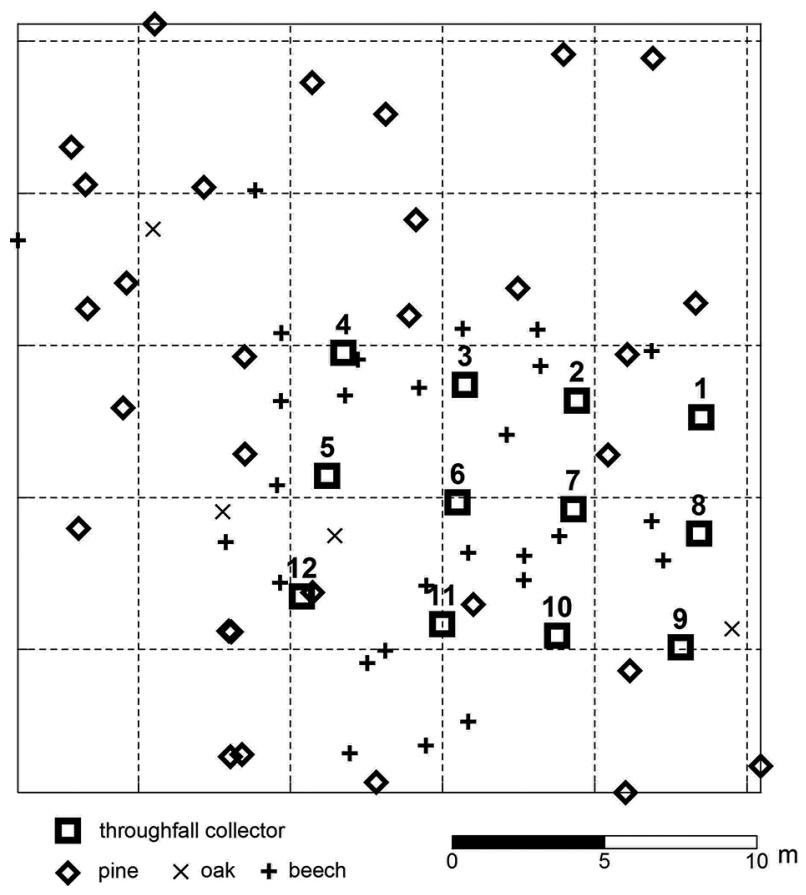

Fig. 1. Site plan of the research area 
through. Funnels with a diameter of $12 \mathrm{~cm}$ were used. Both the funnel and the containers were made from plastic materials, which did not influence the chemical composition of precipitation. To reduce water loss in the vaporisation process, the containers were sunk into the ground and placed inside a PVC pipe. Together with deposition measurements under tree crowns, observations of the chemical composition of precipitation in the area of a totally cleared woodland at a distance of $50 \mathrm{~m}$ from the test area. The bulk precipitation was measured in the open area. Field collectors were exposed in one-month periods or shorter if a lot of precipitation occurred (in summertime). To keep the comparability of the results, the collector exposure times for throughfall and bulk precipitation were identical (Thimonier 1998).

The scope of analyses included the quantity of precipitation and its basic physicochemical parameters: electrolytic conductivity, the $\mathrm{pH}$ and the concentration of main ions (chlorides, sulphates, nitrates, sodium, potassium, magnesium, ammonium ions as well as calcium). The quantity of precipitation, $\mathrm{pH}$ and electrolytic conductance was measured for separately for each collector on the sample collection day. The other parameters were determined for the combined samples. The samples were combined proportionately, including the quantity of precipitation at individual sites. After filtering, samples were stored in a refrigerator at $+4^{\circ} \mathrm{C}$ until the analysis.

The electrolytic conductivity and $\mathrm{pH}$ measurements were performed using a multifunctional meter CX-741 by Elmetron. Anion concentrations (sulphates, chlorides, nitrates) were determined using the ion chromatography method with a DX-120 chromatograph by Dionex. The ammonium ion content was determined by means of the Nessler colorimetric method using the Spekol 1100 spectrophotometer by Carl Zeiss. The atomic emission spectroscopy was used for measuring sodium and potassium concentrations, while atomic absorption spectroscopy was used for measuring calcium and magnesium concentrations. The measurements were performed using a SpectrAA-20 plus spectrometer manufactured by Varian.

All chemical analyses were performed at the laboratory of the Geoecology Station of Adam
Mickiewicz University in Storkowo. The laboratory in Storkowo takes part in inter-laboratory comparative tests of methods for the determination of chemical components in water samples every year. These tests are aimed at assessing the correctness of chemical determinations in control samples from inter-laboratory comparisons organised by the EMEP network.

The statistical analysis included the calculation of seasonal and annual weighted means of physicochemical parameters of precipitation. The quantity of bulk precipitation and throughfall was used as the weight. The ionic load was calculated by multiplying the seasonal means or annual ionic concentrations by the precipitation quantity. As available series of data did not meet the requirements for normal distribution, non-parametric methods were preferred. Statistical calculations were performed using the Statistica 10.0 programme. Graphic analyses were performed using the Grapher 9 program.

To define the degree of transformation of the throughfall, concentrations and enrichment ratios were used. The concentration ratio is the ratio of the concentration of a given ion in throughfall and bulk precipitation (Parker 1983). For the enrichment ratio, the calculation procedure was the same as for the concentration ratio, only ionic loads were used instead of concentrations (Herrmann et al. 2006). To determine the ionic load $\left(\mathrm{K}^{+}\right.$, $\mathrm{Ca}^{2+}, \mathrm{Mg}^{2+}$ ) leached out of the canopy, the canopy budget model was used (Ulrich 1983, Bredemeier 1988, Van der Mass et al. 1991, Draaijers et al. 1995). This model is based on two assumptions:

- sodium ions do not undergo any processes during precipitation permeation through the tree crown area and

- particles containing $\mathrm{Ca}^{2+}, \mathrm{Mg}^{2+}, \mathrm{K}^{+}$ions are of the same size as particles containing $\mathrm{Na}^{+}$.

These assumptions allow for estimating the dry deposition factor (DDF) for these ions according to the following formula (Ulrich 1983):

$$
\mathrm{DDF}=\left(\mathrm{TF}_{\mathrm{Na}}-\mathrm{BP}_{\mathrm{Na}}\right) / \mathrm{BP}_{\mathrm{Na}}
$$

where:

$\mathrm{TF}_{\mathrm{Na}}$ - sodium load raised to the ground with the throughfall,

$\mathrm{BP}_{\mathrm{Na}}$ - sodium load raised to the ground by bulk precipitation. 
The quantity of leaching individual $\mathrm{CL}_{\mathrm{x}}$ ions is calculated according to the following formula (Draaijers et al. 1997):

$$
\begin{gathered}
\mathrm{CL}_{\mathrm{x}}[\mathrm{kg} / \mathrm{ha} / \text { year }]=\mathrm{TF}_{\mathrm{x}}-\mathrm{BP}_{\mathrm{x}}-\mathrm{DD}_{\mathrm{x}} \\
\mathrm{x}=\mathrm{K}^{+}, \mathrm{Mg}^{2+}, \mathrm{Ca}^{2+}
\end{gathered}
$$

where:

DD, TF, BD and CL denote dry deposition, throughfall, bulk deposition and canopy leaching flux of ions, respectively.

The stemfall was not included in this research. In the tree stand under analysis, the quantity of water which gets to the soil in this way corresponds to only $0.2 \%$ of bulk precipitation (Kruszyk 2002).

\section{Research results}

The throughfall is a component of water circulation in forest ecosystems, expressed as the percentage of bulk precipitation, defines the value of tree stand permeability for precipitation. During the three-year research period, the mean pine stand permeability was $73.5 \%$. The average deviation from the mean amounted to $10.7 \%$. In the individual years, the sums of the throughfall ranging from 481.7 to $541.4 \mathrm{~mm}$ constituted 71.5$74.7 \%$ of precipitation.

Taking into account the individual measurement sites, the permeability calculated as the three-year mean fell within the range from 66.1 (site no. 5) to $84.3 \%$ (site no. 4). The lowest tree stand permeability values were observed in November 2012, in the month with the lowest monthly precipitation in the entire research period $(4.7 \mathrm{~mm})$. The average value for the entire research area in this period was $24.5 \%$, with values for individual sites falling within the range from 4.8 to $46.8 \%$.

The chemical composition of the throughfall depends on the degree of atmospheric pollution, amongst other things. The average annual sulphur dioxide concentration in Storkowo, as calculated for calendar years on the basis of daily values, ranged from $4.94 \mu \mathrm{g} / \mathrm{m}^{3}$ in 2010 to 3.34 $\mu \mathrm{g} / \mathrm{m}^{3}$ in 2012 (Szpikowski 2013). These are values, which amount to 25 and $17 \%$ of the allow- able $\mathrm{SO}_{2}$ concentrations due to plant protection $\left(20 \mu \mathrm{g} / \mathrm{m}^{3}\right)$. The nitrogen dioxide concentrations during the research period ranged from $9.67 \mu \mathrm{g} /$ $\mathrm{m}^{3}$ in 2010 to $3.75 \mu \mathrm{g} / \mathrm{m}^{3}$ in 2012. These values constitute 31 and $13 \%$ of the allowable $\mathrm{NO}_{x}$ concentration, respectively, due to plant protection $\left(30 \mu \mathrm{g} / \mathrm{m}^{3}\right)$.

The weighted mean $\mathrm{pH}$ value of bulk precipitation in the period from 2010-2012 was 5.22 and it amounted to 4.95 for throughfall (Table 1). Expressed as the concentration of hydrogen ions, this value was nearly two-fold higher (1.8), as compared to bulk precipitation.

In the period from 2010 to 2012, the annual weighted mean specific electrical conductivity (SEC) of precipitation was at a level of $12.6 \mu \mathrm{S} /$ $\mathrm{cm}$. The throughfall was characterised by higher mineralisation - $33.7 \mu \mathrm{S} / \mathrm{cm}$ - for which an extremely high value was recorded in November $2012(342.0 \mu \mathrm{S} / \mathrm{cm})$, a month with an extremely low total precipitation.

The detailed chemical composition of precipitation in the years 2010-2012 expressed in $\mu \mathrm{eq} /$ $\mathrm{dm}^{3}$ on the basis of weighted means values of annual concentrations of ion components are presented by the following series:

- bulk precipitation

$$
\text { anions: } \mathrm{NO}_{3}^{-}>\mathrm{SO}_{4}{ }^{2-}>\mathrm{Cl}^{-}
$$$$
\text { cations: } \mathrm{NH}_{4}^{+}>\mathrm{Ca}^{2+}>\mathrm{Na}^{+}>\mathrm{Mg}^{2+}>\mathrm{K}^{+}>\mathrm{H}^{+},
$$

- throughfall

anions: $\mathrm{Cl}^{-}>\mathrm{NO}_{3}{ }^{-}>\mathrm{SO}_{4}{ }^{2-}$

cations: $\mathrm{NH}_{4}^{+}>\mathrm{Ca}^{2+}=\mathrm{Na}^{+}>\mathrm{K}^{+}>\mathrm{Mg}^{2+}>\mathrm{H}^{+}$.

For all ions under analysis, the concentrations obtained in the throughfall were higher than values observed in the bulk precipitation. The concentration ratio is the parameter which shows the scale of changes occurring in the chemical composition of precipitation during their contacts with the plant surface. This parameter defines how many times the concentration of a given ion increased in the throughfall as compared to the bulk precipitation. Values higher than 1 indicate the presence of throughfall enrichment processes with a given element. Figure 2 presents the average values of concentration rations for the years 2010-2012 and extreme values calculated on the basis of single measurements. The lowest values for this parameter were recorded for calcium and nitrates. Potassium concentrations in the throughfall for all the periods were by at 
Table 1. The physical-chemical parameters of bulk precipitation (BP) and throughfall (TF)

\begin{tabular}{|c|c|c|c|c|c|c|c|c|c|c|c|c|}
\hline \multirow{3}{*}{ Statistics } & \multirow{3}{*}{ Rain } & $\mathrm{pH}$ & SEC & $\mathrm{Cl}^{-}$ & $\mathrm{NO}^{3-}$ & $\mathrm{SO}_{4}{ }^{2-}$ & $\mathrm{NH}^{4+}$ & $\mathrm{Na}^{+}$ & $\mathrm{K}^{+}$ & $\mathrm{Mg}^{2+}$ & $\mathrm{Ca}^{2+}$ & \multirow{2}{*}{$\frac{\mathrm{H}+}{\mu \mathrm{g} / \mathrm{dm}^{3}}$} \\
\hline & & - & $\mu \mathrm{S} / \mathrm{cm}$ & \multicolumn{8}{|c|}{$\mathrm{mg} / \mathrm{dm}^{3}$} & \\
\hline & & \multicolumn{11}{|c|}{2010} \\
\hline \multirow{8}{*}{$\begin{array}{l}\text { weighted } \\
\text { mean }\end{array}$} & $\mathrm{BP}$ & 5.15 & 11.3 & 0.38 & 1.13 & 0.85 & 0.57 & 0.52 & 0.30 & 0.14 & 0.81 & 7.0 \\
\hline & $\mathrm{TF}$ & 4.82 & 29.6 & 1.11 & 1.98 & 1.47 & 2.24 & 0.90 & 1.77 & 0.32 & 1.03 & 15.2 \\
\hline & \multicolumn{11}{|c|}{2011} & \\
\hline & $\mathrm{BP}$ & 5.25 & 13.2 & 0.54 & 1.63 & 0.97 & 0.57 & 0.50 & 0.21 & 0.12 & 0.56 & 6.8 \\
\hline & $\mathrm{TF}$ & 5.05 & 36.7 & 2.04 & 2.84 & 2.15 & 2.77 & 1.14 & 2.14 & 0.33 & 1.07 & 9.0 \\
\hline & \multicolumn{11}{|c|}{2012} & \\
\hline & $\mathrm{BP}$ & 5.28 & 13.8 & 0.80 & 1.54 & 0.94 & 0.96 & 0.78 & 0.23 & 0.13 & 0.84 & 5.2 \\
\hline & $\mathrm{TF}$ & 5.05 & 35.4 & 2.76 & 2.84 & 1.98 & 2.19 & 1.56 & 1.92 & 0.39 & 1.01 & 9.0 \\
\hline \multicolumn{13}{|c|}{ 2010-2012 } \\
\hline $\begin{array}{l}\text { weighted } \\
\text { mean }\end{array}$ & \multirow{5}{*}{ ВР } & 5.22 & 12.6 & 0.55 & 1.41 & 0.91 & 0.68 & 0.59 & 0.25 & 0.13 & 0.74 & 6.1 \\
\hline $\min$ & & 4.65 & 6.93 & 0.19 & 0.08 & 0.47 & 0.10 & 0.23 & 0.08 & 0.05 & 0.11 & 0.2 \\
\hline $\max$ & & 6.65 & 51.3 & 1.64 & 6.95 & 6.15 & 4.22 & 2.32 & 0.74 & 0.41 & 2.21 & 22.4 \\
\hline SD & & - & 8.9 & 0.41 & 1.25 & 0.99 & 0.85 & 0.38 & 0.18 & 0.08 & 0.52 & 4.9 \\
\hline $\mathrm{Cv}(\%)$ & & - & 71 & 74 & 89 & 108 & 124 & 63 & 73 & 57 & 71 & 82 \\
\hline $\begin{array}{l}\text { weighted } \\
\text { mean }\end{array}$ & \multirow{6}{*}{$\mathrm{TF}$} & 4.95 & 33.7 & 1.94 & 2.53 & 1.85 & 2.39 & 1.19 & 1.94 & 0.34 & 1.04 & 11.2 \\
\hline $\min$ & & 4.32 & 15.8 & 0.22 & 0.10 & 0.41 & 0.34 & 0.43 & 0.66 & 0.19 & 0.30 & 0.2 \\
\hline $\max$ & & 6.78 & 342.0 & 15.32 & 27.64 & 50.34 & 10.73 & 4.67 & 22.6 & 3.59 & 14.2 & 48.2 \\
\hline SD & & - & 54.0 & 2.84 & 4.97 & 7.86 & 2.25 & 0.89 & 3.64 & 0.55 & 2.22 & 12.4 \\
\hline $\mathrm{Cv}(\%)$ & & - & 160 & 147 & 196 & 425 & 94 & 75 & 188 & 160 & 214 & 111 \\
\hline Wk(-) & & - & 2.7 & 3.5 & 1.8 & 2.0 & 3.5 & 2.0 & 7.8 & 2.6 & 1.4 & 1.8 \\
\hline
\end{tabular}

$\mathrm{SEC}$ - electrical conductivity, SD - standard deviation, $\mathrm{Cv}$ - coefficient of variation, Wk - concentration ratio (TF/BP).

least 2.5 times higher than values recorded for the bulk precipitations; in extreme cases, they were 36 times higher.

The analysis of the Spearman rank correlation coefficient showed that for a majority of ions in the throughfall, their distributions were correlated with each other. The highest correlation coefficient values were obtained for the following pairs: $\mathrm{Na}^{+}$and $\mathrm{Cl}^{-}(\mathrm{R}=0.908$, significance level $\alpha=0.000), \mathrm{K}^{+}$and $\mathrm{Ca}^{2+}(\mathrm{R}=0.689, \alpha=0.000), \mathrm{Na}^{+}$ and $\mathrm{Mg}^{2+}(\mathrm{R}=0.721, \alpha=0.000), \mathrm{NO}_{3}{ }^{-}$and $\mathrm{SO}_{4}{ }^{2-}(\mathrm{R}$ $=0.678, \alpha=0.000)$ and $\mathrm{K}^{+}$and $\mathrm{Mg}^{2+}(\mathrm{R}=0.649$, $\alpha=0.000)$. A less significant relationship was obtained for the $\mathrm{K}^{+}$and $\mathrm{Na}^{+}$pair $(\mathrm{R}=0.457, \alpha=$ $0.004)$. No relationships were found between hydrogen ion concentrations and nitrates and sulphates. For all ions, apart from $\mathrm{H}^{+}$, statistically significant negative relationships were obtained depending on the height of the throughfall.
To determine factors affecting the throughfall acidity level, a multiple regression analysis was performed. The concentrations of $\mathrm{SO}_{4}{ }^{2-}, \mathrm{NO}_{3}{ }^{-}$and $\mathrm{NH}_{4}{ }^{+}$were used as independent variables, while the $\mathrm{H}^{+}$ion concentration was the dependent varia-

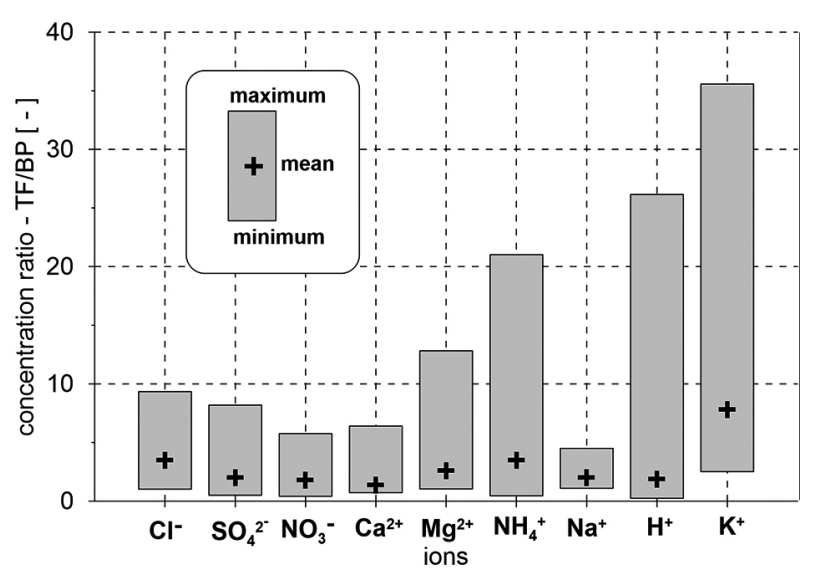

Fig. 2. Mean, minimum and maximum values of concentration ratios 
ble. All variables were logarithmized. The results obtained confirmed that nitrates were responsible for the throughfall acidification ( $\beta$-coefficient $=0.441, \alpha=0.035)$. The sulphate share proved to be statistically insignificant $(\beta$-coefficient $=$ $-0.110, \alpha=0.600)$. Also, the ammonium ions play a significant role in shaping the acid-base balance $(\beta$-coefficient $=-0.591, \alpha=0.001)$. They are a factor which lowers the throughfall acidity.

One of the basic parameters necessary for the assessment of the element circulation in a forest ecosystem includes the element load introduced to the ground with the precipitation.

Despite the reduction of water inflow to the forest floor as a result of the interception process, the total load of ions recorded in the pine stand $(66.55 \mathrm{~kg} / \mathrm{ha} /$ year) exceeded the value observed for the bulk precipitation nearly twice $(36.07 \mathrm{~kg} /$ ha/year) (Fig. 3A). The total inflow of inorganic nitrogen $\left(\mathrm{N}_{-} \mathrm{NO}_{3}{ }^{-}+\mathrm{N}^{-} \mathrm{NH}_{4}^{+}\right)$in the tree stand under analysis was $12.22 \mathrm{~kg} / \mathrm{ha} /$ year (the mean value for the years 2010-2012). The ammonium nitrogen deposition amounted to $76.4 \%$ of the total load of this element. For the bulk precipitations, these values amounted to $5.84 \mathrm{~kg} / \mathrm{ha} /$ year and $63.2 \%$, respectively. As compared to $\mathrm{N}_{-} \mathrm{NH}_{4}{ }^{+}$, for which the enrichment ratio was equal to 2.5, the $\mathrm{N}-\mathrm{NO}_{3}{ }^{-}$depositions in the bulk precipitation and in the throughfall were similar (enrichment ratio $=1.3$ ) (Fig. 3B). The greatest differences in the deposition between the pine stand and the open area were recorded for potassium (the enrichment ratio $=5.7$ ).

The canopy budget model allowed for the calculation of potassium, magnesium and calcium loads leached out of the canopy and raised to the ground with the throughfall. The average annual load $(7.22 \mathrm{~kg} / \mathrm{ha} /$ year) of leached-out potassium calculated for the three-year period constituted $74.1 \%$ of the total deposition $(9.74 \mathrm{~kg} / \mathrm{ha} /$ year $)$ of this element under tree crowns. For the individual years, these values ranged from 71.3 to $77.2 \%$. The share of washed-off dry deposition in the $\mathrm{K}^{+}$ inflow to the forest floor was $8.4 \%(0.82 \mathrm{~kg} / \mathrm{ha} /$ year).

For magnesium, the share of leaching processes was at a level of $25.4 \%(0.41 \mathrm{~kg} / \mathrm{ha} /$ year $)$, while the dry deposition washing amounted to $24.8 \%(0.43 \mathrm{~kg} /$ ha/year $)$.

No processes of leaching out calcium from the canopy were observed in the tree stand under analysis. The recorded load under tree crowns was the sum of dry and wet deposition only.

The division of the year into a growing season (May-October) and a non-growing season season (November-April) allowed for distinguishing groups of ions differing in concentration and load levels during these seasons (Fig. 4). For potassium and ammonium ions, the highest concentrations and charges in the throughfall were observed in the growing season. For loads, differences between the distinguished seasons were higher
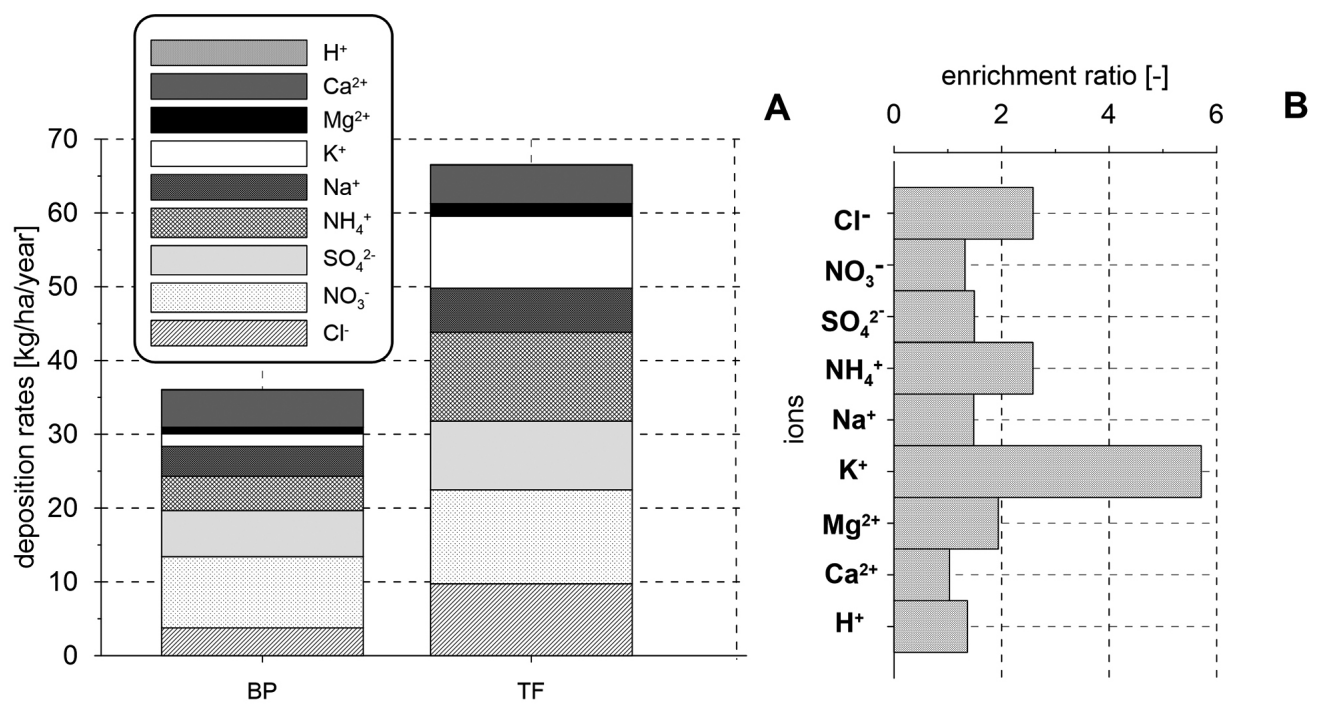

Fig. 3. Size and structure of loads brought to the ground with the bulk precipitation (BP) and with throughfall (TF) (A) and the distribution of the enrichment ratio (B) - mean annual values for the years 2010-2012 
than those found for concentrations. This results from the occurrence of greater quantities of precipitation, as compared to the remaining part of the year. During the three-year research period, the total precipitation from May to October constituted $60 \%$ of the annual value on average.

For hydrogen ions, sulphates, nitrates, chlorides and sodium, the highest concentrations in the throughfall were observed in a period from November to April. Apart from $\mathrm{Cl}^{-}$and $\mathrm{Na}^{+}$, for which loads were comparable for both seasons, deposition during the non-growing season prevailed for the remaining ions. No significant differences were found between calcium and magnesium concentrations in the bulk precipitation and in the throughfall. Higher loads of the aforementioned ions, on the other hand, were recorded in the growing season, especially for the throughfall.

In the period from November to April, increased mineralisation was observed, both for the throughfall and for the bulk precipitation. The weighted mean conductivity in the throughfall was equal to $40.2 \mu \mathrm{S} / \mathrm{cm}$, while in the bulk precipitation, it amounted to $14.3 \mu \mathrm{S} / \mathrm{cm}$. In the growing season, these values amounted to: 29.5 and $11.3 \mu \mathrm{S} / \mathrm{cm}$, respectively.

The canopy model was used to calculate the difference between the potassium and magnesium loads leached out in the growing season and during the remaining part of the year. For potassium, the difference between the seasons was 5.1\% (69.2-74.4\%), while for magnesium, it amounted to $1.9 \%(22.5-24.4 \%)$. The canopy leaching rate was the highest during the growing season. This regularity was observed each year. Magnesium leaching, on the other hand, was the highest in the period from November to April.

On the basis of the three-year measurement series, a statistical testing analysis was conducted, which was aimed at determining whether the existing differences between the deposition in the bulk precipitation and in the throughfall were statistically significant. The non-parametric Mann-Whitney test was used for this purpose. The tests included both the entire research period and measurements in the growing season and in the remaining part of the year. For the majority of ion components, statistically significant differences were obtained between deposition in the

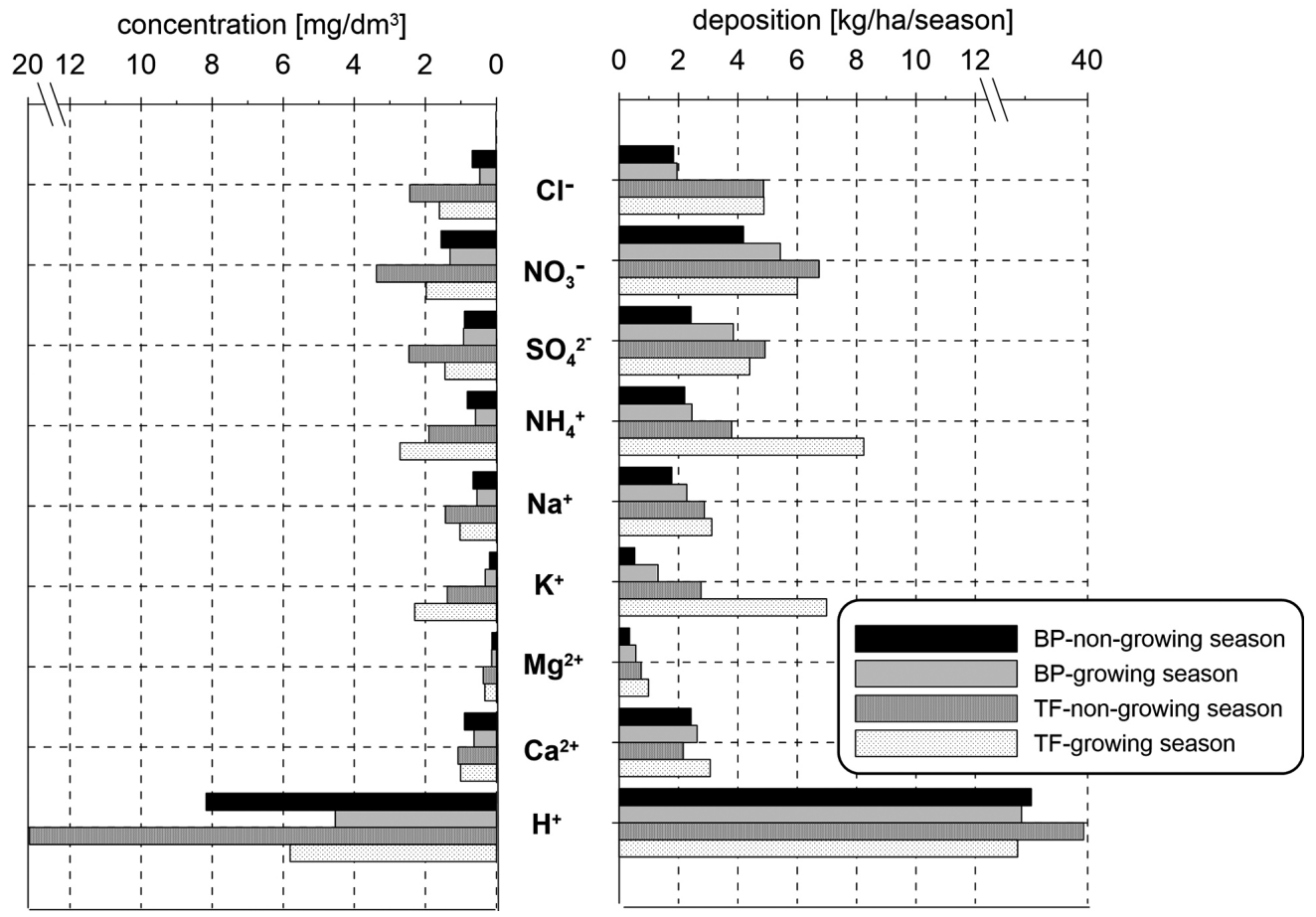

Fig. 4. Concentration and loads of anions and cations in bulk precipitation (BP) and throughfall (TF) of non-growing season and growing season for the period 2010-2012

For hydrogen ions, the concentrations are specified in $\mu \mathrm{g} / \mathrm{dm}^{3}$, while loads are in $\mathrm{g} / \mathrm{ha} /$ season 
Table 2. The results of the Mann-Whitney U-test for differences between the load in the throughfall and in the bulk precipitation

\begin{tabular}{|l|c|c|c|c|c|c|c|c|c|}
\hline & $\mathbf{H}^{+}$ & $\mathrm{Cl}^{-}$ & $\mathrm{NO}_{3}^{-}$ & $\mathrm{SO}_{4}^{2-}$ & $\mathbf{N H}_{4}^{+}$ & $\mathbf{N a}^{+}$ & $\mathbf{K}^{+}$ & $\mathbf{M g}^{2+}$ & $\mathrm{Ca}^{2+}$ \\
\hline whole year & - & $*$ & - & $*$ & $*$ & $*$ & $*$ & $*$ & - \\
\hline non-growing season & - & $*$ & $*$ & $*$ & $*$ & - & $*$ & $*$ & - \\
\hline growing season & - & $*$ & - & $*$ & $*$ & $*$ & $*$ & $*$ & $*$ \\
\hline
\end{tabular}

*a difference significant at $\alpha \leq 0.05,-$ a difference significant at $\alpha>0.05$.

bulk precipitation and in the throughfall (Table 2). Hydrogen, nitrates (except for the period from November to April) and calcium ions (excluding the growing season) are an exception here.

\section{Discussion}

Throughfall is one of the ways of chemical substances getting to the forest floor. Its chemical composition depends of physicochemical parameters of atmospheric deposition, amongst other things. The bulk precipitation under analysis is poorly mineralised and contains multi-component water. Low concentrations of ionic components in precipitation result from good air quality in the area under analysis.

The weighted mean electrical conductivity calculated on the basis of results obtained over the three-year period allowed for classifying this precipitation as low-conductivity precipitation (0.0 $15.0 \mu \mathrm{S} / \mathrm{cm})$, according to classification by Jansen, Block, Knaack (Leśniok 1996). Aftergoing through the canopy, the mineralisation of precipitation increased by nearly three times (2.7) to reach a considerably elevated level $(30.1-45.0 \mu \mathrm{S} / \mathrm{cm})$.

The increase in the throughfall mineralisation results from the pollutant filtering process, both gas and dust pollutants present in the atmosphere and leaching out of elements from needles and leaves (Likens et al. 1995, Grodzińska et al. 1996, Hansen 1996, Małek et al. 2008, Kozłowski et al. 2012). A higher reception surface of needles and their presence in the winter period allows conifer stands to capture pollutants present in the air in a particularly effective manner.

Nitrate nitrogen was found in the group of ions, which are characterised by the lowest increase in the throughfall (the enrichment ratio $=$ 1.3). Similar values for conifer stands are quoted by Fernandez-Sanjurjo et al. (1997) - 1.1 (NW Spain), Terauda et al. - 1.0 (Latvia), Herrmann et al. (2006) - from 1.9 to 2.5 (NW Germany). The ammonium nitrogen load, on the other hand, was nearly three times higher (2.6) than the deposition in the bulk precipitation. This level is similar to values (2.3-4.1) provided for conifer stands by Hermman et al. (2006). Higher enrichment values (5.0) are quoted by Walna et al. (1999) for deciduous and coniferous stands situated near Poznan in the Wielkopolski National Park. The presence of ammonium ions in precipitation is connected with organic matter decomposition processes, biomass combustion, production of fertilizers, emission by plants and combustion of fossil fuels (Schrijver et al. 1998, Małek et al. 2008). In the light of the research conducted so far, it is assumed that $\mathrm{NH}_{4}^{+}$ions can be taken up from precipitation in the canopy area (Van der Maas et al. 1991). The $\mathrm{NH}_{4}^{+}$values obtained in the tree stand under analysis are more likely to indicate processes of precipitation enrichment with ammonium nitrogen as a result of dry deposition being washed off. Marques et al. (2001) estimated the $\mathrm{NH}_{4}{ }^{+}$dry deposition and the gas $\mathrm{NH}_{3}$ share in the total ammonium nitrogen load in the Solling forest (Germany) at $66 \%$. The recorded total nitrogen load of $12.22 \mathrm{~kg} /$ ha/ year $\left(\mathrm{N}^{-\mathrm{NO}_{3}}{ }^{-}+\mathrm{N}^{-} \mathrm{NH}_{4}{ }^{+}\right)$was below the critical nitrogen load (15-20 kg N/ha/year) provided by Małek et al. (2008) for conifer stands.

Potassium is one of the elements whose presence in the throughfall results from canopy leaching. The share of this process in the tree stand under analysis was estimated at $74.1 \%$ of the potassium deposition in the throughfall. Pajuste et al. (2006) obtained values ranging from $40-73 \%$ for pine and spruce stands in Estonia. Similar values were quoted by Herrmann et al. (2006) for two pine stands situated in north-west Germany $(44-71 \%)$. Research conducted by Kozłowski et al. (2012), on the other hand, showed that the share of leached out potassium in spruce stands was $88.9 \%$ and it amounted to $91.6 \%$ in fir stands. Małek et al. (2008) for spruce stands at various 
ages situated in Silesian Beskids, received values ranging from 10 to $78 \%$, depending on the tree stand age and the season (growing season vs. non-growing season). The intensity of potassium leaching processes depends on many factors. The most important of these include: the type and age of the tree stand (Małek et al. 2008, Kozłowski et al. 2012), canopy density (Whelan et al. 1998, Herrman et al. 2006), distance from the edge of the forest (Devlaeminck et al. 2005) and inflow of acidifying compounds from the atmosphere (Draaijers et al. 1997, Polkowska et al. 2005, Małek et al. 2008). In accordance with Wood and Bormann's views (1975), potassium, as compared to magnesium and calcium, is leached out more easily as it is weakly bounded in the tissue structure.

No processes of leaching out calcium from the canopy were observed in the tree stand under analysis. The lack of these processes results from the deficiency of this element in the soil. For the remaining ions $\left(\mathrm{SO}_{4}{ }^{2-}, \mathrm{NO}_{3}{ }^{-}, \mathrm{NH}_{4}^{+}, \mathrm{H}^{+}, \mathrm{Na}^{+}, \mathrm{Cl}^{-}\right)$, the observed increase in the throughfall deposition resulted only from the washing off of dry deposition and the concentration of the solution as a result of precipitation interception.

Changes occurring during the contact between precipitation and the plant surface in forest ecosystems do not only include an increase in the mineralisation, but also affect their acid-base balance. In the classification of bulk precipitation performed in accordance with the acidity classification proposed by Jansen, Block and Knaack (quoted after Leśniok 1996), the value obtained was regarded as the normal $\mathrm{pH}$ (5.1-6.0). After getting through the canopy, the $\mathrm{pH}$ of the precipitation was slightly lower (4.6-5.0).

The $\mathrm{pH}$ values obtained for the throughfall are comparable to results obtained by other authors. Pajuste et al. (2006) provide values ranging from 4.8-5.6 for pine and spruce stands in Estonia. Terauda et al. (2007) obtained values ranging from 5.4-5.8 for pine stands in Lithuania in 2004, while Hermmann et al. (2006) reported the $\mathrm{pH}$ of the throughfall of 5.6 in north-west Germany. The research conducted by Kozłowski et al. (2012) on a fir stand in the Świętokrzyskie Mountains and on a spruce stand on the borderline between the Low Beskid and Pogórze Karpackie (Carpathian Foothills), the $\mathrm{pH}$ values amounted to 3.99 and 4.14 , respectively. Researchers associate the oc- currence of highly acidified throughfall with the occurrence of long-term acidic immision of local and remote origin (Kozłowski et al. 2012).

On the basis of the conducted distribution analysis of hydrogen ion, nitrate and sulphate distribution during the year, it can be concluded that throughfall acidification processes occur mostly during the non-growing season. During this time, the difference between the $\mathrm{pH}$ of the bulk precipitation and the throughfall amounted to 0.38 with a value of $0.11 \mathrm{pH}$ units during the growing season.

The lack of a statistically significant difference between the distribution of hydrogen ions in the bulk precipitation and in the throughfall shows that the acidification processes in the pine stand are not very intensive. This situation is influenced by decreasing sulphur dioxide concentrations in the area. In the catchment area of the upper Parsęta river, a systematic decrease in sulphate concentrations has been observed since the 1990 (Szpikowska 2012). On the other hand, nitrates play a growing role in the acidification of precipitation. As indicated by Szpikowska (2013), a distinctly higher share of nitrogen oxide in the acidification of precipitation has been observed in the past 6 years, as compared to sulphur dioxide. This is confirmed by the calculated acidogenic factor index in the acidification of precipitation (Szpikowska 2013), expressed by the ratio of equivalent concentrations of nitrate ions to sulphate ones. It amounted to 1.06 (average for the years 2010-2011). Apart from nitrates, the throughfall acidification level is influenced by ammonium nitrogen, the presence of which contributes to a decrease in the precipitation acidity in pine stands.

\section{Conclusions}

Despite the reduction of the throughfall as a result of the interception process, the total load of ions introduced to the soil in the pine stand exceeded the values obtained for bulk precipitation. An increased inflow of elements to the forest floor resulted from leaching processes $\left(\mathrm{K}^{+}, \mathrm{Mg}^{2+}\right)$ and the washing off of dry depositions $\left(\mathrm{Na}^{+}, \mathrm{Cl}^{-}\right.$, $\mathrm{SO}_{4}{ }^{2-}, \mathrm{NO}_{3}{ }^{-}, \mathrm{NH}_{4}{ }^{+}, \mathrm{Mg}^{2+}$ ).

For a majority of ions, apart from nitrates and hydrogen ions, statistical differences were ob- 
tained between depositions in the bulk precipitation and in the throughfall.

The share of leaching processes for $\mathrm{K}^{+}$was $74.1 \%$, while for $\mathrm{Mg}^{2+}, 23.6 \%$ of the total load of these elements brought to the ground with throughfall. No leaching processes were observed for calcium. The total load under tree crowns was the sum of dry and wet deposition only.

Precipitation while permeating the canopy undergoes acidification - the $\mathrm{pH}$ of the throughfall in the period under analysis was lower by 0.27 units as compared to the bulk precipitation. Nitrates are responsible for throughfall acidification. The share of sulphates proved to be statistically insignificant.

\section{Acknowledgment}

This paper is supported by the founds intendend by Polish Ministry of Science and Higher Education for science in years 2008-2012 as research project No N305 337334.

\section{References}

Bochenek W., Jóźwiak M., Kijowska M., Kozłowski R., 2008. Zróżnicowanie opadu podkoronowego w wybranych ekosystemach leśnych w Górach Świętokrzyskich i w Beskidzie Niskim (Differentiation of throughfall in select sylvan ecosystems in Świętokrzyskie Mountains and Low Beskids). Monitoring Środowiska Przyrodniczego 9: 47-55.

Bredemeier M., 1988. Forest canopy transformation of atmospheric deposition. Water Air Soil Pollution. 40: 121-138.

Butler T.J., Likens G.E., 1995. A direct comparison of throughfall plus stemflow to estimates of dry and total deposition for sulfur and nitrogen. Atmospheric Environment 29(11): 1253-1265.

Dambrine E., Pollier M., Bonneau M., Ignatova N., 1997. Use of artificial trees to assess dry deposition in spruce stands. Atmospheric Environment 32(10): 1817-1824.

Devlaemnick R., De Schrijver An., Hermy M., 2005. Variation in throughfall deposition across a deciduous beech ( $F a$ gus sylvatica L.) forest edge in Flanders. Science of the Total Environment 337: 241-252.

Draaijers G.P.J., Erisman J.W., 1995. A canopy budget model to assess atmospheric deposition from throughfall measurements. Water Air Soil Pollution 85: 2253-2258.

Draaijers G.P.J., Erisman J.W., van Leeuwen N.F.M., Romer F.G., Te Winkel B.H., Veltkamp A.C., Vermeulen A.T., Wyers G.P., 1997. The impact of canopy exchange on differences observed between atmospheric deposition and throughfall fluxes. Atmospheric Environment 31(3): 387-397.

Fernandez-Sanjurjo M.J., Fernandez Vega V., Garcia-Rodeja E., 1997. Atmospheric deposition and ionic concentration in soils under pine and deciduous forests in river Sor atchment (Galicia, NW Spain). The Science of the Total Environment 204: 125-134.

Gower C., Rowell D.L., Nortcliff S., Wild A., 1995. Soil acidification: comparison of acid deposition from the atmosphere with inputs from the litter/soil organic layer. Geoderma 66: 85-98.

Grodzińska K., Laskowski R., 1996. Ocena stanu środowiska i procesów zachodzacych w lasach zlewni Potoku Ratanica (Pogórze Wielickie, Polska Potudniowa) (Environmental assessment and processes in forest Ratanica catchment, Pogórze Wielickie, Southern Poland). Biblioteka Monitoringu Środowiska. Warszawa.

Hansen K., 1996. In-canopy throughfall measurements of ion fluxes in Norway spruce. Atmospheric Environment 30(23): 4065-4076.

Herrmann M., Pust J., Pott R., 2006. The chemical composition of throughfall beneath oak, birch and pine canopies in Northwest Germany. Plant Ecology. 184: 273-285. DOI 10.1007/s11258-005-9072-5.

Kostrzewski A., Kruszyk R., Kolander R., 2006. Zasady organizacji, system pomiarowy, wybrane metody badań. Zintegrowany Monitoring Środowiska Przyrodniczego (Integrated Monitoring of Environment. The principles of organization, the measuring system, the selected test methods). On-line: http:/ / www.staff.amu.edu.pl/ zmsp/dok.html (accessed 29 June 2013).

Kozłowski R., Jóźwiak M., Jóźwiak M., Bochenek W., 2012. Ocena wielkości wymywania jonów $\mathrm{K}+, \mathrm{Ca} 2+\mathrm{i} \mathrm{Mg} 2+$ w wybranych drzewostanach w warunkach kwaśnej depozycji (Assessment of $\mathrm{K}+, \mathrm{Ca} 2+$ and $\mathrm{Mg} 2+$ volume leaching in selected tree stands under conditions of acidic deposition). Sylwan. 156(8): 607-615.

Kruszyk R., 2002. Wpływ roślinności na procesy denudacji chemicznej w strefie młodoglacjalnej (Pomorze Zachodnie, zlewnia górnej Parsęty) (Effect of vegetation on chemical denudation processes in postglacial area, Western Pomerania, upper Parsęta catchment). Manuscript.

Kvaalen H., Solberg S., Clarke N., Torp T., Aamlid D., 2002. Time series study of concentrations of SO42- and $\mathrm{H}+$ in precipitation and soil waters in Norway. Environ. Pollution 117: 215-224.

Leśniok M., 1996. Zanieczyszczenie wód opadowych w obrębie Wyżyny Ślasko-Krakowskiej (Pollution of precipitation in the Silesia-Cracow Upland). Wyd. Uniwersytetu Śląskiego, Katowice.

Likens G.E., Bormann F.H., 1995. Biogeochemistry of a forested ecosystem. Springer Verlag, New York, Berlin, Heidelberg, London, Paris, Tokyo, Hong Kong, Barcelona, Budapest.

Małek S., Astel A., 2008. Throughfall chemistry in spruce chronosequence in southern Poland. Environmental Pollution 155: 517-527.

Marques M.C., Gravenhorst G., Ibrom A., 2001. Input of atmospheric partieles into forest stands by dry deposition. Water Air, Soil Pollution 130: 571-576.

Pajuste K., Frey J., Asi E., 2006. Interactions of atmosferic deposition with coniferous canopies in Estonia. Environmental Monitoring and Assessment. 112: 177-196. DOI: 10.1007/s10661-006-0360-x.

Parker G.G., 1983. Throughfall and stemflow in the forest nutrient cycle. Adv. Ecol. Res. 13: 58-120.

Polkowska Ż., Astel A., Walna B., Małek S., Mędrzycka K., Góreski T., Siepak J., Namieśnik J., 2005. Chemometric analysis of rainwater and throughfall at several sites in Poland. Atmospheric Environment 39: 837-855. 
Schrijver de An., Nachtergale L., Roskams P., De Keersmaerker L., Mussche S., Lust N., 1998. Soil acidification along an ammonium deposition gradient in a Corsican Pine stand in northern Belgium. Environmental Pollution 102: 427-431.

Shubzda J., Lindberg S.E., Garlen C.T., Nodvin S.C., 1995. Elevation trends in the fluxes of sulphur and nitrogen in throughfall in the Southern Appalachian Mountains: some surprising results. Water, Air and Soil Pollution 85: 2265-2270.

Szpikowska G., 2012. Zmiany stężeń jonów siarczanowych w wodach powierzchniowych zlewni górnej Parsęty w wieloleciu hydrologicznym 1994-2011 (Changes in concentrations of sulphate ions in surface waters of the upper Parsęta catchment in hydrological multi-year 1994-2011). In: A. Kostrzewski, J. Szpikowski (eds.), Zintegrowany Monitoring Środowiska Przyrodniczego. Funkcjonowanie geoekosystemów w różnych strefach krajobrazowych Polski. Biblioteka Monitoringu Środowiska, XXIX, Storkowo: 71-82.

Szpikowska G., 2013. Chemizm opadów atmosferycznych (The chemistry of precipitation). In: A. Kostrzewski (ed.), Raport Stacji Bazowej ZMŚP w Storkowie za rok 2012. Manuscript.

Szpikowski J., 2013. Zanieczyszczenie powietrza (Air pollution) In: A. Kostrzewski (ed.), Raport Stacji Bazowej ZMŚP $w$ Storkowie za rok 2012. Manuscript.

Terauda E., Nikodemus O., 2007. Sulphate and nitrate in precipitation and soil water in pine forest in Latavia. $\mathrm{Wa}$ ter Air Soil Pollution 7: 77-84. DOI: 10.1007/s11267-0069066-x.

Thimonier A., 1998, Measurment of atmospheric deposition under forest canopies: some recommendations for equip- ment and sampling data. Environmental Monitoring and Assessment. 52: 353-387.

Ulrich B., 1983.A concept of forest ecosystem stability and of acid deposition as driving force for destabilization. In: B. Ulrich, J. Pankrath (eds.), Effects of accumulation of air pollutants in forest ecosystems. D. Reidel Publ. Co., Dordrecht: 1-29.

van Breemen N., Driscol C.T., Mulder J., 1982. Acidic deposition and internal proton sources in acidification of soils and waters. Nature 307: 599-604

van der Mass M.P., Pape Th. 1991. Hydrochemistry of two Douglas fir stands in the Netherlands. Internal publication. Department of Science and Geology, Agricultural University of Wageningen.

Walna B., Siepak J., 1999. Research on the variability of physico-chemical parameters characterising acid precipitation at the Jeziory Ecological Station in the Wielkopolski Park (Poland). The Science of the Total Environment. 239: 173-187.

Whelan M.J., Sanger L.J., Baker M., Anderson J.M., 1998. Spatial patterns of throughfall and mineral ion deposition in a lowland Norway spruce (Picea Abies) plantation at the plot scale. Atmospheric Environment 32(20): 3493-3501.

Wood T., Bormann F.H., 1975. Increase in foliar leaching caused by acidification of an artificial mist. Ambio 4: 169171.

Zwoliński Zb., Gudowicz J., 2010. Sprawozdanie z wykonanych prac $w$ ramach zadania "Pokrycie terenu i użytkowania ziemi w zlewniach Stacji Bazowych ZMŚP - mapy inwentaryzacyjne - faza 1" (Report on the work carried out in the framework of the project "Land cover and land use in the catchment Base Station ZMŚP - Maps Inventory - Phase 1"). Manuscript. 